\begin{tabular}{|c|c|}
\hline SOSyolojkbağlam & $\begin{array}{r}\text { ISSN: } 2757-5942 \\
2020,1(1), 66-75 \\
\text { https://doi.org/10.52108/2757-5942.1.1.6 } \\
\end{array}$ \\
\hline Çevrimiçi Basım / Online Publication: 28.12.2020 & Geliş Tarihi/Received: 21.12 .2020 \\
\hline Derleme Makalesi/ Review Article & Kabul Tarihi/Accepted: 27.12.2020 \\
\hline
\end{tabular}

\title{
Geçmiş ve Gelecek Arasında Irak'lı Türkmenler: Politik Uygulamaların Tarihsel Eleştirisi
}

\author{
Iraqi Turkmens Between the Past and the Future: A Historical Critique of \\ Policies
}

\author{
Heersh Hasan MAHMOOD* \\ D0000-0003-2818-8837
}

\begin{abstract}
Öz
Türkmenler Orta Doğu başta olmak üzere dünyanın pek çok bölgesinde yaşamaktadır. Orta doğu bölgesinin en karmaşık yapısına sahip olan ülkelerden Irak, büyük bir Türkmen nüfusunu topraklarında ev sahipliği yapmaktadır. Yüzyıllardır Irak topraklarında yaşayan Türkmenler söz konusu ülkenin etnik yapısını oluşturan en önemli unsurlardan biri olmuştur. Sosyal etkinlik açısından bakıldığında Irak Türkmenlerinin özel bir konuma sahip olduğu görülmektedir. Zira Türkmenlerin ülkede yaşayan diğer etnik gruplara göre daha fazla kendi geleneklerine ve tarihlerine bağlı oldukları görülmektedir. Bu özelliğine karşın Irak Türkmenlerin her daim merkezi otorite tarafından baskı ve șiddete maruz kaldıkları söylenebilir. Bu perspektiften hareketle çalıșmada birbiriyle oldukça bağlantılı olduğu düșünülen iki temel unsur üzerinde durulmaktadır. Türkmenlerin sosyo- kültürel yaşamı, tarih boyunca karşılaştıkları siyasi olaylar ve farklı Irak rejimleri tarafından Türkmenlere uygulanan politikalar tarihsel açıdan ele alınmakta ve tartışılmaktadır. Türkmenlerin Irak toplumsal yapısı içerisinde asli unsur sayılmamaları ve azınlık statüsünde değerlendirilmeleri temel sorun alanını oluşturmaktadır.
\end{abstract}

Anahtar Kelimeler: Tarih, Irak Türkmenleri, Demokratikleșme, İnsan Hakları, Politik Uygulamalar

\begin{abstract}
Turkmens live in many parts of the world, especially in the Middle East. Iraq, one of the countries with the most complex structure of the Middle East region, hosts a large Turkmen population within its territories. Turkmens who have been living in Iraqi lands for centuries are, and have been, one of the most important elements of the ethnic structure of the country in question. Because these ethnic groups are more dependent on their own traditions and history compared to other ethnic groups living in the country, it is seen that the Iraqi Turkmens have a unique place from a social point of view. For this reason, it is crucial to state that the Iraqi Turkmens are always subjected to pressure and violence by the central authority. The study focuses on two basic elements that are thought to be highly interconnected. The socio-cultural life of the Turkmens, the political events they encountered throughout history and the policies implemented on Turkmens by different Iraqi regimes will be evaluated and discussed. The fundamental problem is that the Turkmens are not considered an essential element in the Iraqi social structure and that they are considered as a minority.
\end{abstract}

Keywords: History, Iraqi Turkmens, Democratization, Human Rights, Policies.

\footnotetext{
* Salahaddin University, Faculty of Letters, Department of Sociology. $\bowtie$ hershhasan40@gmail.com
} 


\section{Giriş}

Irak Türkmenleri yüzyıllardır Irak'ta yaşamaktadır ayrıca Türkmenler Irak tarihinde özel bir yere sahiptir. 2003 yllına kadar siyasette hiç faaliyet görmeyen Türkmenler 2003'den sonra siyaset alanında faaliyetlerde bulunmuşlardır. Bu durumun yıllar sonra Türkmenlerin siyaset yaşamına olumsuz bir durum olarak yansıdığı görülmektedir.

Irak'lı Türkmenler haklarını talep edebilmek için hiçbir zaman silahlı eylemlere başvurmamış, devletin varlı̆̆ını üstün tutan ve değerlerine sahip çıkan vatandaşlar olmuşlardır. Türkmen halkının demografik yapısına bakıldığında, Türkmenler ülkenin en kalabalık nüfusuna sahip üçüncü milletini oluşturduğu görülmektedir. Tek istekleri kendi topraklarında insanca yaşamak olan Türkmenler, tarihten günümüze kadar uygulanan demokrasi olmayan politikalarına rağmen millî varlıklarını devam ettirmeye çalışmışlardır. Olumsuz şartlara ve zorluklara rağmen, millî kimliklerini, dillerini ve kültürlerini korumuşlardır. Irak'ın toprak bütünlüğünü sağlama yönünde politika yürüten Türkmen toplumu siyasî, idarî ve kültürel haklarına kavuşma özlemi içerisindedir.

Osmanlı döneminde Irak’ta yaşayan Türkler, yüzyıllar boyunca yönetici konumunda bulunmuşlardır. Bu durum İngilizlerin Irak'ı işgal etmesiyle sona ermiştir. Irak'ın kurucu unsurlarından birisi olan Türkmenler, Irak Hükümeti'nin Türkmenlere uyguladığı politikalar neticesinde dağınık bir coğrafyaya dağılmışlardır. Türkmenler, Irak'ın en güneyindeki Basra'dan en kuzeye kadar hemen hemen her vilayette bulunmaktadır. Fakat Türkmenlerin çoğu toplu olarak Irak'ın kuzey bölgesinde yaşmaktadır. Yoğun olarak Irak'ın kuzey batısından güney doğusuna kadar yaklaşık 50 kilometrelik geniş bir alanda yaşamlarını idame ettirmektedirler. 1926 Ankara Antlaşması sonucunda Irak ve Türkiye arasında çizilen sınır ile birlikte Türk toplumu, Irak'taki yönetimleri tarafından baskı görmüş ve bir tehdit olarak algılanmıştır. Kaynaklarda 1950'lilerin sonunda ilk dönemlerde kullanılan "Türk" adının yerine, Türkiye ile bağların koparılması amacıyla "Türkmen" adının kullanıldığı ifade edilmektedir. Türkmenler, Türkiye'ye güven neticesinde ortaya çıkan rehavet hali ve Baas Rejiminin baskıcı politikaları nedeniyle de bölgede hakim anlayış olan silahlı mücadeleyi tercih etmemiş, siyasal hareketlerden uzak durarak, kültürel, sosyal yapıları ve kendi kimliklerini korumaya odaklanmıştır.

\section{$2 \quad$ Irak'ın Sosyal ve Etnik Yapısı \\ 2.1 Irak'ın Etnik Yapısı}

Irak devleti sosyal ve etnik yapı açısından karmaşık bir yapıya sahiptir. Irak'ta yaşayan etnik grupların bir kısmı göç ederek Irak topraklarına yerleşmişlerdir. Diğerler ise bin yıldır Irak'ta yaşamaktadır. Irak topraklarında dilsel ve dinsel olarak farklı geçmişe sahip pek çok farklı etnik grup yaşamaktadır. Köken olarak her etnik grup farklı soylardan gelmektedir. Dinsel olarak büyük bir kısmı Sünni ve Şii Müslümanlardan oluşmaktadır. Bunların yanı sırada Hıristiyan, Yezidi, Şebekler, Aşurilar ve Keldaniler var olduğunu bilinmektedir. Dilsel olarak Irak anayasasında Arapça, Kürtçe ve Türkmence (Erkmen, 2010: 110) üç resmi dil olarak kabul edilmiştir.

Yukarda belirttiğimiz grupların sayıları hakkında şimdiye kadar ortada net bir bilgi yoktur. Çünkü Irak'ta 1957 yıldan itibaren temiz ve güvenilir bir nüfus sayımı yapılmamıştır. 1958 yılındaki darbeden önce yapılan nüfus sayımı, siyası hedefler için kullanılmaya yönelik olarak düzenlenmediğinden son güvenilir ve temiz bir nüfus sayımı olarak kabul edilmektedir. Bu durum Irak'ta o tarihten itibaren hiç nüfus sayımı yapılmadığı anlamına gelmemektedir. Ayrıca tüm Irak'ı kapsayan son sayım 1987 yllında, Irak'ın kuzeyinin dahil edilmediği genel son nüfus sayımı ise 1997 yılında yapılmıştır. Fakat bu sayımlar siyası amaçlar için yapıldığından verilen rakam ve bilgiler gerçek olarak kabul edilmemektedir. Irak'ın nüfusunun büyük bir kısmı Araplardan oluşmaktadır. Irak'ın kuzeyi dışında bir başka deyişle Erbil, Duhok, Süleymaniye ve Kerkük dışında kalan 14 kent ise büyük çoğunlukla Araplardan oluşmaktadır. Araplardan sonra ikinci büyük etnik grup ise Kürtlerdir ve çoğunlukla Erbil, Süleymaniye ve Duhok'ta yaşamaktadırlar. Ayrıca, Musul, Kerkük ve Diyala'da hatırı sayılır bir Kürt nüfus olduğu bilinmektedir. Ülkede Türkmenler ise çoğunlukla Erbil, Kerkük ve Musul șehirlerinde yașamaktadır. Bu kentlerin yanı sıra Selahattin ve Diyala'nın bazı ilçe 
ve kasabalarında çok sayıda Türkmen yaşamaktadır. Bu üç büyük etnik grup sadece sayıca çoğunlukta değil aynı zamanda siyasi, sosyal ve ekonomik açllardan da etkinlerdir. Asuri, Yezidi, Keldani ve Şebekler daha çok Irak'ın orta ve kuzey kesimlerinde yaşamaktadırlar (Erkmen, 2010: 111).

\subsection{Irak'ın Dini Yapısı}

Irak nüfusunun yaklaşık \%60'ını Arap Şiiler oluşturmaktadır. Fakat Kürtler ve Türkmenler arasında sayısı az da olsa Şiiler bulunmaktadır. Irak Şiilerinin dini ve kutsal merkezleri Necef ve Kerbela'dır, Çünkü Şiilerin çoğu kutsal mezarları Necef ve Kerbela'da bulunmaktadır. Şiilerden sonra nüfusun \%30'unu Sünniler oluşturmaktadır. Sünniler ayrıca Kürtler ve Türkmenler arasında da çoğunluğa sahiptir. Irak’ın bağımsızlığı sonrası Sünni azınlık yüzyıllarca ülkeyi yönetmiştir. Fakat 2003 yılından sonra ABD'nin Irak'ı işgal etmesiyle Şiiler iktidara gelmişlerdir. Hıristiyanlar ise Irak nüfusunun yaklaşık \%3'ünü oluşturmaktadır. Ayrıca Çoğu Hıristiyanlar Keldani-Asuri kilisesine bağlıdır, son yıllar savaş ve etnik çatışmadan dolayı birçok Hıristiyanlar ülkeyi terk ederek yurt dışına kaçmışlardır (Yılmaz,2012: 227)..

\subsection{Aşiretçilik}

Orta Doğunun tarihini ve toplumsal yapısını anlamak için en kilit kavramları üretmiş olan İbni Haldun, Mukaddime adlı kitabında bugün kullanılan aşiretçilik ve aşiret kavramının esası olan nesebiyeti tanımlarken iki farkı tanımdan bahsetmektedir: Nesep Asabiyeti ve Sebep Asabiyeti. Bugüne gelindiğinde Irak'taki aşiretlerin oluşma süreçleri ve esas davranış şekilleri bağlamında hala bu tanımlamanın büyük bir ölçüde doğru olduğu ortaya çıkmaktadır. Fakat, 20. Yüzyıl Irak siyasi tarihi üzerine yapılan araştırmalarda Irak'ta 2003'ten önce üç tip aşiret olduğu bilinmektedir: İlk olarak Devletçi aşiretler, sosyal aşiretler ve askeri ideolojik aşiretlerdir. Bunlardan birinci kategoride olanlar, aşiret bağları, sembolleri ve kültürü yönetici elitin statüsü, iktidarını ve meşruiyetini güçlendirmek için devletle entegre olmuş aşiretlerdir. Bunlar Baas partisi döneminde özellikle Saddam Hüseyin yönetimi altında büyük bir güç kazanmışlardır. Sosyal aşiretler ise modern kent yaşamı içinde güç kaybeden ve ülkedeki siyasi ve sosyal yapıyı kontrol etmeyen devlet aygıtının yerel aşiretleri kullanmasıyla medyana gelmektedir. Özellikle 1980'li yılların ortası ve 1990'lı yıllarda Saddam Hüseyin, yönetimindeki ve taşradaki birçok aşireti bu hedefle kullanmıştır. Bu sebeple, bu aşiretler 1991 yılından sonra bazı ayrıcalıklar ve çıkarlar karşılığında Saddam Hüseyin'e hizmet etmişler ve rejimin güvenliği sağlamışlardır. Üçüncü aşiret tipi ise askeri-ideolojik aşiretçiliktir. Özellikle Kürt bölgelerinde meydana gelen bu aşiretçi yaklaşım, daha sonra rejime ve Bass partisine karşı yürütülen muhalefetin ve isyanların belkemiğini oluşturmuştur (Erkmen, 2010: 114).

\section{Irak'ta Türkmen Varlığı ve Türkmen Kavramı}

Türkmen kavramı ile ilgili çalışan Türk tarihçilerine göre farklı farklı görüşler ortaya çıkmaktadır. Bunların en önemlisi ve bir çok bilim adamının üzerinde durduğu husus ise Türkmenlerin Türk boylarından biri olduğudur. Fakat diğer bir husus ise Türkmenler 11. yüzyıldan sonra oğuz boyunlarından gelen bir isimdir. Ayrıca Türkmen isminin Selçuklu döneminde kullanılmaya başlandığı bilinmektedir. Türkmen kelimesi araştırılan tarihi kaynaklara göre farklı anlamlarda kullanmaktadır. Türkmen ifadesi ilk defa XI. yüzyılda Kaşgarlı Mahmut'un Divanı-ı Lügat-it Türk isimli eserinde karşımıza çıkmaktadır. Türklerden İslamiyet ile ilk tanışanlara bu adın verildiği bilinmektedir. Nitekim Kaşgarlı Mahmut'un bu konuda Türk ve İman şeklinde bir açıklaması vardır. Türkmen sözlügüne göre ise Türkmen kelimesi“ Büyük Türk, Türklük, Türkler, Koyu Türk” olarak ifade edilmektedir. 0 dönemden itibaren günümüze kadar iki görüş hakim olmuştur. Bunlardan biri Türk ismi Farsça "man” ekinden gelmiş olup “Türk’e benzer" anlamına gelmektedir. XIV. yüzyılda İran'da "Türkmen" kelimesinin bu șekilde oluştuğu kabul edilmektedir. İkinci görüş ise "Türkmen" kelimesinin "Türk-i iman dan" geldiği görüşüdür. Bu ifadenin Müslüman Türk anlamında kullanıldığı bilinmektedir Fakat bu görüşü İbn Kesir ve Mehmed Neşri de kabul etmektedir. En çok kabul edilen diğer bir görüș ise Müslüman Oğuzlara Türkmen isminin verildiği görüştür. Oğuzlar, İslamiyet'i kabul edene kadar kendilerine uzun bir dönem Türkmen dememişlerdir (Doğan, 2018: 2.). 
Oğuz boyuna mensup olan Türkmenler Orta Asya'dan gelerek Irak'a yerleşmeye başlamışlardır. Yirmi dört Oğuz boyundan biri olan Bayat boyunun büyük çoğunluğu, Irak'ın kuzeyindeki Türkmenli bölgesinde yaşamaktadır. Dede Korkut ve ünlü şair Fuzuli de Bayat boyundandır. Neredeyse bütün tarihçiler, Oğuz Türkmenlerinin Müslümanlığı kabul ettikten sonra "Türkmen" olarak anılmaya başlandığı konusunda hemfikirdir. Milattan önceki dönemlerde Orta Asya'dan yapılan göçler neticesinde Mezopotamya bölgesine çeşitli Türk boylarından geldiği bilinmektedir. Türklerin düzenli ve kalıcı olarak Irak'a göç süreçleri üç farklı dönemde incelenebilir. Bu dönemlerden birincisi Sasani Devleti'nin yıkılması ile başlamıştır. Türkmenlerin, Irak'a yerleşmeleri çeşitli zamanlarda devam etmiştir. Türkmenlerin, Irak’a ilk girişleri Emeviler zamanında Hicri 54 (Miladi 674) tarihine kadar gitmektedir (Maruf, 2001:7).

Türkmenlerin Irak'a göçlerinin ikinci evresi Selçuklu Devleti döneminde olmuştur. Selçukluların Irak topraklarına girmesiyle birlikte Türkmenlerin yerleşme ve yurt edinmek amacıyla göç etmesi ikinci dönemin başlangıcını oluşturmuştur. Bundan sonra bölgenin hakimiyeti tam olarak Türklerin eline geçmiş, bu zamanda Türkmenler, Irak'a kalabalık gruplar halinde gelerek çeşitli şehirlere yerleşmişlerdir. Böylelikle Irak'a gelen Türkmenler, beylikler ve devletler kurmuşlardır. En yoğun yerleşme süreçleri olan bu dönemde Türkmenler Irak'ı kendilerine yurt edinmiş ve vatan olarak benimsemişlerdir. Bölgenin Osmanlı hakimiyetine girmesinin ardından, daha önceki senelerde bölgeye göç eden Türkmenlerle Osmanlı idarecileri ve askerleri arasındaki kaynaşma, Türkmenlerin bölgeye yerleşmesini sağlamıștır. Bu süreçte Irak'lı Türkler önemli mevkilere gelmișlerdir (Yılmaz, 2005:6).

Irak'a Türkmen göçünün son dalgası ise Osmanlı Devleti döneminde yaşanmıştır. Osmanlı Devleti, Musul bölgesini Yavuz Sultan Selim'in 1514 yılındaki Çaldıran Savaşından sonra 1516 yılında kontrol altına almıştır. Kanuni Sultan Süleyman'ın Irak'a gerçekleștirdiği seferle birlikte Bağdat Osmanlı Devleti tarafından alınmış ve Türk hâkimiyeti bütün Irak'a yayılmıştır. Irak, Osmanlı Devleti ile Safeviler arasında IV. Murat dönemine uzanan çekişmelere rağmen Birinci Dünya Savaşı'ndaki İngiliz ileri harekâtına (1917) kadar, yaklaşık dört yüz sene Osmanlı Devleti yönetimi ve medeniyeti hakimiyetinde kalmıştır (Güngör, 2014: 17).

\section{Irak Türkmenlerinin Karşı Karşıya Kaldığı Politikaların Dönemsel İncelemesi}

\subsection{Birinci Dünya Savaşı Sonrası}

Osmanlı Devleti'nin yıkılması ile birlikte 1920-1932 yılları arasında Irak'ın İngiliz Mandası altında bulunduğu dönemde Türkmenler baskı ve zulmün başlayacağı bir döneme girmişlerdir. 1930 İngilizIrak antlaşması ile manda yönetiminin sonra ermesi ve Irak'ın 1932 yılında Milletler Cemiyeti'ne kabul edilmesi sonrasında bağımsızlı̆̆na kavuşmasıyla birlikte Irak Türkmenlerinin karşılaştıkları baskı ve şiddet katlanarak artmıştır. 1920 yılında İngilizler tarafından hazırlanan geçici Anayasası ile Irak halkının Arap, Türkmen ve Kürt milletlerinden oluştuğu kabul edilmiştir. Bu anayasanın 14. maddesi gereğince Türkmenlere ana dilleri (Türkmence) ile öğrenim görme hakkı tanınmış olmasına rağmen bu haktan mahrum bırakılmışlardır (Çobanoğlu, 1994: 168).

1932'de bağımsızlık kazanan Irak yönetimi yaklaşık 70 kadar Türkmen öğretmeni Arap bölgelerine sürdürmüştür. Böylece Irak rejimi Türkmenlere ve Arap olmayanlara yönelik yönelik farklı bir politika uygulamaya başlamıștır. 1932'de bütün Türkmen bölgelerinde ve tüm dereceli okullarda eğitimin Arapça yapılması kabul görmüştür. Böylelikle günümüze kadar çoğu Iraklı Türkmenler Arapça dili ile eğitim almaktadır. Türkmence ise sadece aile içinde konuşulabilen ve öğrenilebilen bir dil olarak kalmıştır. Kral 1. Faysal, Başbakan Nuri Sait Paşa ve 1933'de Kral olan Gazi dönemlerinde Türkmenlere uygulanan baskılar artmıştır (Çobanoğlu, 1994: 168).

1936 yllında hükümet başkanlığına getirilen Memlûk Türklerinden Hikmet Süleyman'ın iki sene sonra istifa etmesinin ardından Irak Türklerine yapılan baskılar daha fazla artmıștır. 1937 yılında Türkiye, Irak, Iran ve Afganistan arasında oluşturulan Sâdâbâd Paktı vesilesiyle Irak'a giden Türk heyeti Kerkük ziyaretinde yoğun ilgi görmüştür. Bunun ardından, pek çok Türkmen aydını sürgün 
edilmiştir. Bu olaydan sonra da Türkiye'den gelen heyetin bölgeyi ziyaret etmesine Irak yönetimi tarafından izin verilmemiştir. Bu süreçte Irak Türkmenlerine yönelik ilk katliam gerçeklemiştir. Kerkük'te petrol şirketinde çalışan Türkmen iş̧̧ilerin çalışma koşullarının iyileştirilmesi talebiyle düzenlemiş oldukları toplantı ve yürüyüşe 12 Temmuz 1946 tarihinde polis kuvvetleri ateş açmıştır. Irak yönetimi, Türkmenlerin direniş hareketlerini sindirmeye çalışmıştır. Kendi dillerinde yayın yapma ve eğitim verme gibi pek çok temel hak ve hürriyetleri kısıtlanmış ya da bütünüyle yasaklanmıştır (Güngör, 2014: 21). Ayrıca Türkmenlere ait olan bütün derneklerin faaliyetleri ve kültürel ve sosyal faaliyet gösteren dernek kurmaları yasaklanmıștır. 1955 yılına gelindiğinde Türkiye, Irak, İngiltere, İran ve Pakistan arasında imzalanan Bağdat Paktı sayesinde daha ılımlı ilişkiler gündeme gelmiştir. Fakat bu gelişmeler de Türkmenlere yönelik baskı ve asimilasyon faaliyetlerinin azalmasını engellememiştir (Güngör, 2014: 22).

\subsection{Irak İhtilali Sonrası Türkmenlerin Durumu}

Irak Kraliyet rejimi Birinci Dünya Savaşı sonrasından uyguladığı İngiltere yanlısı politikalar neticesinde 1957 yılının temmuz ayında, General Abdülkerim Kasım liderliğinde Arap Milletçi ve solcu subayların işbirliği ile askeri darbe gerçekleștirmiștir. Bu askeri darbe sonucunda Irak'ta Kraliyet rejimi sona ermiş ve yerine Cumhuriyet ilan edilmiștir. İthal'den sonra darbeci askerler radyodan verdikleri beyanlarda, Irak'ın üç temel etnik gruptan meydana geldiğini ve Türkmenlerin de bunlardan birisi olduğunu bildirmiştir. Bu bildiri Türkmenler tarafından baskıların sona erdiği şeklinde yorumlanmış ve Cumhuriyet rejiminin açılklk ve demokrasi getireceğine inanarak bu ihtilali desteklemişlerdir. Fakat beklenen gibi olmamış ve yeni iktidar sözünde durmamıștır. Darbecilerin 27 Temmuz 1958 tarihinde çıkardıkları geçici anayasada ilk kez vatandaşlık eşitliği iptal edilmiş ve üçüncü maddeye yeni bir hüküm eklemişlerdir: " Irak'ın varlığı bütün vatandaşları işbirliği, haklarının korunması ve hürriyetlerin güvence altına alınması esasları üzerine kurulur. Araplar ve Kürtler bu vatanda ortaktırlar ve Irak'ın birliği çerçevesinde Milli hakları korunur". Maddeden de anlaşlabileceği üzere Türkmenler bu anayasa ile beraber azınlık durumuna düşürülerek isimleri dahi yer almamıștır. ${ }^{1}$

İhtilal'ın ardından Türkmenler kendi seslerini duyurabilmek adına 23 Eylül 1958 günü Türkmen aydınların öncülüğünde "Beşir" isimli gazete çıkarmaya başlamıștır. 1 Şubat 1959 yllında Bağdat radyosu günlük bir saat Türkmence yayın yapmaya başlamıştır. Ancak ülkede Arap Milliyetçilerle Komünistler arasında yaşanan çekişmeler sebebiyle istikrarsızlıklar söz konusu olmuştur. Ülke genelinde yapılan öğrenci birliği seçimlerini her yerde Komünistler kazanırken Kerkük'te Türkmenler kazanmıștır. Aynı sonuçlar Öğretmenler Sendikası için de geçerli olmuştur. Bu da Kerkük'ün Komünistlere karşı direnmesinin en büyük göstergesi olarak yorumlanabilir. Bu gelişmeler üzerine iktidarda olan Komünist parti Türkmenlere uyguladığı politikaları gözden geçirmiştir (Silleli, 2005: 125). 1959 yllından itibaren Irak Yönetimi Türkmenlere uyguladığı baskıları arttırmıştır. Yeni yayın hayatına başlayan Beşir gazetesinin kapatmasının yanı sıra gazetenin yazarları ve idarecileri ile Kerkük'ün ileri gelenlerinden oluşan pek çok avukat, doktor ve işadamı sürgüne göndermiştir (Silleli, 2005: 126). Ayrıca bu dönemde Türkmenlere yönelik büyük bir katliamlar gerçekleştirilmiştir. "59 Kerkük katliamı" olarak bilinen bu katliam Cumhuriyetin birinci yılı kutlamaları esnasında yaşanmıştır. Bu kutlamalar sırasında Komünist Partisine mensup militanları Türkmen mahallerine yönelik saldırılarıyla katliama başlamıştır. Kutlamalara katılmak üzere sokaklarda olan Türkmenler, resmi geçit sırasında Komünist Militanlar hedefi haline gelmiștir. Ayrıca bu olaylardan sonra sokağa çıkma yasağı ilan edilmesine rağmen Türkmenlerin evlerine gerçekleştirilen saldırılar devam etmiştir. Toplu yok etme amacı taşıdığı aşikar olan bu katliamlar arasında Türkmenlerin lider kadroları da hedef olarak alınmıştır. 3 gün süren bu olaylarda yüzlerce

\footnotetext{
${ }^{1}$ Duman, B. http://orsam.org.tr/orsam/gencorsam/11467?dil=tr (erişim tarihi: 19.12.2017).
} 
Türkmen vatandaşı şehit olmuş ve yaşananlar Irak Türkmenlerine yönelik en kanlı katliamlardan birisi olarak tarihe geçmiştir. ${ }^{2}$

\subsection{Bass Partisi'nin Türkmenlere Uyguladığı Politikalar}

Irak'ta Bass Partisi 1963 yıllında gerçekleştirdiği bir darbe ile iktidara gelmiştir. Bu darbe sonucunda Devlet başkanlığına Abdüsselam Arif, Başbakanlığa ise Albay Ahmet Hasan El-Bekr getirilmiştir. Yasama ve yürütme yetkileri ise Ulusal Devrim Komuta Konseyi'ne verilmiştir. Bu dönemde Kerkük katliamı sebebiyle hakkında idam hükmü verilen 28 kişi, 23 Haziran 1963 tarihinde Kerkük'te idam edilmiştir. Böylece Türkmenler bu tarihten sonra nispeten istikrarlı bir döneme girmişlerdir. Fakat kültürel hakların elde edilmesi konusunda herhangi bir gelişme olmamıştır. Vatandaşların ülkeye hizmetlerini artırmanın, millî birliği koruma ve mücadele azmini derinleştirmenin, onların meşru haklarına kavuşmaları ile sağlanacağını savunan darbeciler, Türkmen azınlığın yaşadığı bölgelerde kültürel haklarını kullanabilmelerini uygun görmüștür. Dolayısıyla ihtilal Komuta Konseyi 24 Ocak 1970 tarihli “Azınlıklara Kültürel Haklar Paketi” çerçevesinde Türkmenlere bazı haklar tanınmıştır:

- İlkokullarda Türkmen dili okutulmasını,

- Bu dilde öğretim yapan bütün okullarda açıklama usullerinin Türkmen diliyle yapılmasına,

- Türkmence öğretimi hususunda Terbiye ve Talim Bakanlığı'na bağlı bir müdürlüğün kurulmasına,

- Türkmen edebiyatçı, şair ve yazarlarının, kendilerine mahsus bir birlik kurmalarına imkân verilmesine, eserlerini bastırabilmek için yardım edilmesine dil bakımından kabiliyetlerini artırma fırsatı verilmesine ve bu birliğin Irak Edebiyatçılar Birliği’ne bağlanmasına,

- Kültür ve Tanıtma Bakanlığı'na bağlı olan bir Türkmen Kültür Müdürlüğü kurulmasına,

- Dili Türkmence olan haftalık bir gazete ve aylık bir dergi çıkartılmasına,

- Kerkük televizyonundaki Türkmence yayınların artırılmasına karar verilmiștir. ${ }^{3}$

Fakat bu haklar kağıt üzerinde kalmış hiç birisi hayata geçirilmemiştir. Irak yönetiminin özellikle bu dönemde Türkmenlere kültürel haklarını vermesinin temel sebebi, BM Genel Kurulu'nun 1961 Aralık ayında her türlü ırk ayrımcılı̆̆ının tasfiye edilmesine ilişkin alınan karardır. Örgüte üye ülkelerin imzalanması için hazırlanan belge ocak ayında yürürlüğe girmiştir (Hasan, 2003: 46).

Irak Baas partisi Hükümetinin yasama ve yürütme organı 1968 ve 1979 tarihleri arasında tamamen Sünni Arap Baasçllardan oluşmaktaydı. Irak hükümetin kabinesi, parlamento üyeleri ve 18 bölgenin valisi Saddam Hüseyin'in başkanlık yaptığı Devrim Komuta Konseyi tarafından tayin edilirdi. 1973 yılında Irak hükümeti totalitarizm anlayışına doğru hareket etmesinde güvenlik güçlerinde yeniden organize ve toparlanmaya başladı. Baasçılar, Almanlar, KGB ve Sovyet gizli polisinden eğitim ve sorgulama için özel çalışma konusunda tavsiyeler aldı. Daha sonra 1974 yılında Türkmen, Şii Arap ve Kürtlere baskı altına almak için hareket başlattı. Türkmenlere 24 Ocak 1970 yılında verilen kültürel haklar bir yıl sürmeden geri alınmış aynı zamanda Türkmen milliyetçileri tutuklanmaya ve idam ettirilmeye başlanmıştır. Irak'ta sadece Türkmenlere karşı değil aynı zamanda diğer milletlere özelikle Kürtlere ve Arap Şiilere de benzer politikalar uygulanmıştır. Bu dönemde Baas Partisi'nin Irak’a uyguladığı politikalar yüzünden başta Türkmenler olmak üzere bütün Irak halkı için acı ve talihsiz bir dönem yaşanmıştır (Maruf, 2001: 63). 1979 yılından itibaren Bass rejimi Türkmenlere uyguladığı baskıları arttırmıştır. Türkmenlerin lider konumunda yer alan önemli kişiler gözaltına alınmış, kimisi işkence görmüş hatta idam edilenler olmuştur. Bağdat Üniversitesinde öğretim üyesi olan Doç. Dr. Necdet Koçak ve Dr. Rıza Demirci'nin yanı sıra müteahhit Adil Şerif tutuklanmıştır.

\footnotetext{
2 Alptekin, G. 14 Temmuz 1959 Kerkük Katliamı ve Irak Türkmenlerinin Durumu, http://www.yeniufukdergisi.com/14-temmuz-1959-kerkuk-katliami-ve-irak-turkmenlerinin-durumu/ (erişim tarihi 19.12.2017).

${ }^{3}$ Asimerik Savaşlar, https://asimetriksavaslar.wordpress.com/2011/03/30/irakli-turkmenlere-yonelik-etnik-temizlik/ (erişim tarihi 19.12.2017).
} 
Ayrıca Saddam Hüseyin, İran-Irak savaşında Türkmenleri savaşın ön saflarında savaşmak zorunda bırakmıştır. Öte yandan bu dönemde Bazı Türkmenler Şii olmalarından dolayı Saddam tarafından suçsuz yere idam edilmiştir (Yllmaz, 2012: 221-222). Saddam Hüseyin döneminde Kerkük'te 600 metre genişliğinde bir otoyol inşa edileceği gerekçesiyle, Türkmenlere ait yaklaşık iki bin evi yıktırmıştır. Otoban inşaatı bitince bütün bu evler, Araplara verilmiş ve Kerkük'ün Araplaştırılması planında bir adım daha ileriye gidilmiştir (Yılmaz, 2012: 222).

Körfez Savaşının ardından Kuzey Irak'lı Kürtler ayaklanmaya başlamışlardır. Bu ayaklanmalar sırasında Mart 1991'de Kerkük ve çevresinde yoğun çatışmalar yaşanmıştır. Bu olaylardan dolayı Bağdat Yönetimi askerlerini Kerkük şehrinden geri çekmiştir. Bu durumu firsat bilen Kürtler, 18 Mart 1991'de Kerkük'e girerek öncelikle Bass Partisinin önde gelen üyelerini hedefleyen saldırılar başlatmışlardır. Bu saldırlar neticesinde Bass Partisine üye birçok Baas'lı öldürülmüştür. Ancak Irak Yönetiminin Kürtleri bastırması için gönderilen Cumhuriyet Muhafızları, 26 Mart'ta önce Türkmenlerin yaşadığı ilçelerden Tuzhurmatu'ya ulaşarak buralarda birçok masum Türkmen'i katletmiştir. Irak Hükümetinin Körfez Savaşında uğradığı hezimet adeta Türkmenlerden çıkarılmış gibi görünmektedir (Yllmaz,2012: 224).

\subsection{ABD'nin Irak İşgali Sonrasında Türkmenler ve Kerkük'ün Statüko Sorunu}

ABD'nin Irak işgali sonrasında, Irak'ın yeniden yapılandırılması çalışmaları ve bununla birlikte ifade özgürlüğünün görece gelişmesiyle, Irak'taki tüm etnik ve dini gruplarda olduğu gibi Türkmenler arasında da yeni siyasi oluşumlar ortaya çıkmıștır. Ancak 1995'ten günümüze kadar Türkmenleri temsiliyeti ve tanınırlığı açısından Irak Türkmen Cephesi'nin Türkmenler tarafından en fazla tanınan siyasi kuruluş olduğunu söylemek mümkündür. Türkmenler, işgalden sonra yeniden şekillenen Irak siyasetinde etkin bir rol oynamamışlardır. Ayrıca Türkmenler, işgalden sonra ABD tarafından oluşturulan 25 kişilik Geçici Yönetim Konseyinde sadece bir kişiyle temsil edilmiştir. Türkmenlerin tek temsilcisi olan Songül Çabuk'un seçilmesi de yönetimde kadınlara tanınan kotadan yararlanmasından kaynaklanmaktadır (Duman, 2011: 24). ABD’nin Türkmenlere karşı uyguladığı demokrasi olmayan politika açıkça görülmektedir. Amerikalı yetkililerin açıklamalarına göre 25 kişi de Irak'taki nüfus yapısına göre belirlenmiştir. Oysa Irak'ta Türkmen nüfus olarak üçüncü etniğe sahiptir. Asurîlerin nüfusu ise Türkmenlerden daha az olduğunu görülmektedir. Fakat Geçici Konseyde Kürtlere 5 sandalye ve Asurîlere 1 sandalye verilirken, Türkmenlere sadece 1 sandalye verilmiştir.

Irak Geçici Yönetim Konseyi, Irak Geçici İdare Yasası'nı hazırlamıştır. Bununla birlikte ABD yönetimi Türkmenlerin haklarının anayasa ile güvence altına alınacağını açıklamıştır. Bu gelişme Türkmenler tarafından sevinçle karşılanmıștır. 1 Haziran 2004'te Irak Geçici Yönetim Konseyi bir toplantı düzenlemiş ve oluşturulan Bakanlar Kurulu'nda Türkmenlere iletişim ve Teknoloji Bakanlığı verilmiștir. Reşad Ömer Mendan'a verilen bu konum, aslında kaotik bir görünümün olduğu ülkede önem taşımamaktadır. Yönetim böylece Türkmenleri siyasal anlamda etkisiz hale getirmiş ve olası itirazların önüne geçmeye çalışmıştır. Ayrıca 2005 ve 2010 seçimlerinde Türkmenlere çeşitli bakanlıklar verilmiştir. 2005 yılında kabul edilen Irak Anayasası, Türkmenlerin varlığını kabul etmiş ancak Kuzey Irak'ta Kürtlere tanındığı gibi özerk bir bölge ya da vilayet tayin edilmemiştir. Dolayısıyla söz konusu anayasa Türkmenlere, Kürtlere tanıdığı şekilde geniş haklar tanımamıştır. Türkmenler azınlıklar için yer alan bazı bireysel haklardan yararlanabilmektedirler (Çankara, 2010: 729).

$\mathrm{Bu}$ noktada Türkmenler bir takım dilsel haklar kazanmış ancak kültürel özerkliğe sahip olamamışlardır. Söz konusu anayasada Arapça ve Kürtçe ülkenin resmi dili olarak kabul edilmektedir. Ancak daha sonra verilen bir kanun teklifinin onaylanması ile Türkmence, Süryanice ve Aşurice de resmi dil olarak kabul edilmiştir. Böylelikle ilk etapta kamuoyunda ülkede Arapça ve Kürtçe ile birlikte resmi dil sayısının 5'e çıkmış olduğu yönünde bir algı yaratılmıştır. Bu gelişme Türkmenler açısından önemli bir kazanım gibi gözükse de, yasanın sorunlu tarafı bu hakkı Türkmenlere ülke genelinde değil, onların çoğunluk olarak yaşadıkları bölgelerde tanımış olmasıdır. 
Türkmenlerin bundan sonraki hedefi Irak genelinde dillerinin Kürtçe ve Arapça gibi resmi dil olarak kabul edilmesini sağlanmak olmuştur (Çankara, 2010: 730).

Irak'ta savaş sonrasında ülkede tansiyon sürekli yüksek olmuştur. Savaşın ardından ülkenin siyasi yapısını şekillendiren temel unsurlardan biri 'mezhepçilik' olmuştur. 2006-2007 yılları arasında kısmen azalan mezhepler arası gerginlik özellikle ABD askerlerinin çekilmesinin ardından 2011 yılından itibaren yeniden artış göstermiş ve kanlı çatışmalar yaşanmıştır. Bu çatışmalar sırasında Türkmenlere yönelik baskı ve şiddet hareketleri artmıștır. Türkmen halkının kanlı saldırılarda liderlerini ve önemli siyasetçilerini kaybettiğini ifade eden Irak Türkmen Cephesi Başkanı Salihi, Kerkük, Selahaddin ve Musul'da Türkmen vatandaşlarının son 10 yılın en acımasız saldırılarına maruz kaldıklarını dile getirmiştir. Son olarak Salihi, Türkmenleri hedef alan bombalı ve silahlı eylemlerin, ülkedeki şiddet olaylarının bir parçası olarak değerlendirilemeyeceğini ifade etmiştir. Bunların Türkmenleri yok etmeyi hedefleyen planlı saldırılar olduğunu açıklanmıştır. Amacın Türkmenleri kendi kaderine terk etmek ve çatsşmanın ortasında bırakmak olduğunu ifade etmiştir (Güngör, 2014: 31).

\subsection{Kerkük'ün Statüko Sorunu}

Kerkük, Irak'ta en fazla etnik grubu içinde barındıran önemli șehirlerden birisidir. Ayrıca şehir sahip olduğu zengin enerji kaynakları sebebiyle de ülkedeki güç mücadelesinin odağında yer almaktadır. Şehir, belli başlı nüfuz grupları olan Kürtlerin, Arapların ve Türkmenlerin bir yandan kontrol çabalarına, bir yandan da özelliklede Türkmenlerde gözlemlendiği gibi bu çatışmalar içerisinde hayatta kalma mücadelelerine sahne olmuştur. Örneğin Saddam rejimi döneminde bölgede başta Türkmenler ve Kürtler olmak üzere diğer etnik gruplar da göçe zorlanmıș ve yerine Araplar yerleştirilmiştir. 0 dönemde Bass Partisi uyguladığı planlı Araplaştırma politika bilinmektedir. Bu politika şehrin demografisinin değişmesi için bir olanak yaratmıştır (Sadık, 2015: 265).

Irak'ın 2005 yılında kabul edilen Anayasası'nın 140. maddesine göre Kerkük sorununun çözüme kavuşması için normalleşme, nüfus sayımı ve referandumun yapılması gündeme getirilmiştir. Ancak söz konusu maddenin hayata geçirilmesi sürecinde Iraklı taraflar arasında uzlaşı sağlanamayınca 31 Aralık 2007 tarihinde bu madde zaman aşımına uğramıştır. Kerkük 140. maddeyle beraber üç aşamalı plan çerçevesinde yapılması öngörülen referandum ile Bağdat'a veya Irak Kürt bölgesel yönetimine bağlı olacaktır. Referandumun sadece Kerkük halkının değil tüm Irak halkının katılımıyla gerçekleştirilmesi ve kentin geleceğine yönelik ortak bir irade oluşturacak şekilde gerçekleştirilmesi gerekmektedir. Ancak referanduma sadece Kerkük halkının katılımı öngörülmüștür. Zira 2003 işgali sonrası Kerkük'ün Kürtler tarafından demografik yapısı değiștirilmiştir. Kerkük'ün geleceğini belirleyen referandumun yalnızca kentteki etnik grupların katılımıyla gerçekleștirileceği düşüncesi, güçlü olanın demografik yapıyı değiştirmesini de beraberinde getireceğini göstermektedir. ${ }^{4}$ Ayrıca bu maddenin açık ve gizli yanları da bulunmaktadır. Açı olan yanı "ihtilaflı bölge" tabirinin esas itibariyle Kerkük'e karşılık gelmesidir. Gizli olan yanları da ihtilafın Kürtlerle Araplar arasında olduğu ve Kerkük dışında kalan bölgelerin zikredilmemesidir. Bir diğer ifadeyle ihtilafın içinden Türkmenler dışlanmıştır. Nitekim Kürtler ihtilaflı bölgeler olarak Kerkük'ün tamamı; Musul'un Başika, Akra, Sincar ilçeleri; Selahattin'nin Tuzhurmatu ilçesi ve Diyala'nın da Hanekin ilçesi ile Mendeli bucağını tanımlamaktaydılar. Aslında Kerkük'ün dışında diğer şehirlerin ihtilaflı bölge olduğuna dair hiçbir belge ve anlaşma bulunmamaktadır. Musul'un üç ilçesi hariç diğer ihtilaflı yerlerin en büyük müștereği Türkmen ağırlıklı olmasıdır. Kerkük, Tuzhurmatu, Hanekin ve Mendeli bölgeleri 50 yıllık bir süreç içerisinde demografik yapısı planlı şekilde değiştirilmiş Türkmen yerleşim bölgesidir. Buna Altunköprü ve Kifri şehirlerini de katmak mümkündür (Nakip, 2013: 99100). Böylelikle işgalden önce Saddam'ın uyguladığı politikalar ve işgal sonrası Kürt gruplarının

\footnotetext{
${ }^{4}$ Semin, A. Irak.2ta Türkmenlerin Geleceği ve Kerkük'ün Özerklik İhtimali, http://www.bilgesam.org/Images/Dokumanlar/0-51-20150630341225_a.pdf (erişim tarihi 21.12.2017).
} 
uyguladığı eylemler neticesinde, eskiden beri bir Türkmen yerleşim bölgesi olan Kerkük şehrinin demografik yapısı değiştirilerek ve Türkmenlerin șehirden dışlanmaya çalışmışlardır.

\section{Sonuc}

Türk devletlerinin bölgede hakim oldukları dönemlerde Irak'taki Türkmenler bütün sosyal, kültürler ve siyasi haklara sahip olmuşlardır. Ayrıca bu dönemlerde Türkmenler Irak'ın devlet yönetiminde önemli mevkilerde yer almıştır. Fakat Osmanlı İmparatorluğunun yıkılması ve İngilizlerin bölgeye yerleşmesi Irak'taki Türkmenler için zor ve karanlık günlerin başlangıcı olmuştur. İngiliz Mandası tarafından kurulan Irak Devleti'nde Türkmenler asli bir unsur olarak görülmemiştir. Asli unsur için söz konusu olabilecek hususlar Türkmenler için asla geçerli olmamıştır. Türkmenler asli unsur sayılmadıkları gibi azınlık da sayılmamıștır. Uluslararası bir anlașma ile sosyal ve kültürel hakları garanti altına alınmamıştır. Bütün bunların yanı sıra Türkmenler kendilerine uygulanan demokrasi olmayan politikalar sebebiyle büyük baskılara ve şiddete maruz kalmıștır.

1932 yılında bağımsızlığını kazanan Irak devleti Türkmenlere yönelik baskılar devam etmiştir. Bağımsızlıktan sonra yönetimler değişse de bile Türkmenler için yeni bir dönem başlangıcı söz konusu değildir. Ayrıca bu politikalar Türkmenlere karşı devam etmiştir. 0 tarihten sonra Irak'ta iktidara gelen her parti ayni politika uyguladığı söylemek mümkündür. Irak devletinde farklı zamanlarda farklı partiler tarafından Türkmenleri çeşitli sosyal ve kültürel haklar tanınmış ancak bu haklar pek hayatta geçirmemiştir. Baas Partisi iktidarı döneminde Türkmenlere yönelik şiddet ve baskının dozu biraz daha artmıștır. Mart 2003'te ABD'nin Irak'a gerçekleștirdiği müdahale sonrası yeni bir dönem başlangıç ümidi ile siyasette katılmışlar. Fakat daha sonra durum öyle olmadığını ortaya çıkmıştır. Çünkü işgalden sonra Irak ananasında Türkmenlere bazı kültürel siyasal ve sosyal haklar vermişti yalnız bu haklar pek hayatta geçmemiştir.

\section{Kaynakça}

Çankara, Y. (2010). ABD'nin 2003 Irak Operasyonu Sonrasında Irak Türkmenlerin Konumu ve Geleceği, Tarihte Günümüzde Ortadoğu'da Türkmenler (Irak-İran-Suriye), Uluslararası Sempozyumu, Bilecik Şeyh Edebali Üniversitesi.

Çobanoğlu, M. (1994). Türkiye-Irak İlişkilerinin Dünü, Bugünü, Yarını. İstanbul: Harp Akademilerin Basın Evi.

Doğan, S. (2018). Irak Türkmenleri, İnsan ve Sosyal Araştırmalar Merkezi, Sayı 68, İstanbul.

Duman, B. (2011). 2003 Irak Siyasetinde Türkmenler ve Yeni Hükümete Türkmenlerin Durumu. Ortadoğu Analiz Dergisi, 3 (25).

Erkmen, S. (2010) Irak'ta İşgal Sonrası Siyasal Yaşam ve 2010 Parlamento Seçimleri, Ortadoğu Etütleri, Ankara, 2 (3).

Güngör, F. (2014). Ortadoğu Denkleminde Irak Türkmenleri ve Geleceği. Uluslararası Sosyal ve Eğitim Dergisi, I (2).

Hasan, M. (2003). Irak'ın Gizlenen Gerçeği: Türkmenler, Irak Krizi. Özdağ, Ü. (Ed), Ankara: Avrasya Stratejik Araştırmalar Merkezi Yayınları.

Maruf, A. (2001) Türkiye-Irak İlişkilerinde Türkmenler: Körfez savaşı sonrasından Günümüze. (Yayınlanmamış Yüksek Lisans Tezi). Gazi Üniversitesi Sosyal Bilimler Enstitüsü, Ankara.

Nakip, M. (2013). Irak'ta İhtilaflı Bölgeler ve Türkmenler. Ortadoğu Analiz Dergisi. 5 (49).

Sadık, G. (2015). Kerkük'ün Statüsü Krizi. Çakmak, H. (Ed), Türk Dış Politikasında 41 Kriz içinde. Ankara: Kripto Yayınları.

Silleli, T. (2005). Büyük Oyunda Türkiye-Irak İlişkileri. İstanbul: Kültür Sanat Yayınları. 
Yılmaz, S. (2005). Irak Türkmenlerine Yapılan Katliamlar ve Bunun Türk Kamuoyuna Yansımaları (1924-1959). (Yayınlanmamış Yüksek Lisans Tezi). Ankara Üniversitesi Türk İnkılap Tarihi Enstitüsü, Ankara.

Yılmaz, S. (2012). Irak Dosyası. İstanbul: Kum Saat Yayınları.

Iraqi Turkmens Between the Past and the Future: A Historical Critique of Policies

\section{Kaynak Gösterimi / Cite This Article}

\section{APA:}

Mahmood, H.H. (2020). Geçmiş ve Gelecek Arasında Irak'lı Türkmenler: Politik Uygulamaların Tarihsel Eleştirisi. Sosyolojik Bağlam Dergisi, 1(1), 66-75.

Mahmood, H.H. (2020). Iraqi Turkmens Between the Past and the Future: A Historical Critique of Policies. Journal of Sociological Context, 1(1), 66-75.

\section{MLA:}

Mahmood, Heersh Hasan. "Geçmiş ve Gelecek Arasında Irak'lı Türkmenler: Politik Uygulamaların Tarihsel Eleștirisi." Sosyolojik Bağlam Dergisi, c. 1, s. 1, 2020, ss. 66-75.

Mahmood, Heersh Hasan. "Iraqi Turkmens Between the Past and the Future: A Historical Critique of Policies." Journal of Sociological Context, v. 1, i. 1, 2020, pp. 66-75.

\section{Chicago:}

Mahmood, Heersh Hasan. "Geçmiş ve Gelecek Arasında Irak'lı Türkmenler: Politik Uygulamaların Tarihsel Eleștirisi." Sosyolojik Bağlam Dergisi 1, s. 1 (2020): 66-75.

Mahmood, Heersh Hasan. "Iraqi Turkmens Between the Past and the Future: A Historical Critique of Policies." Journal of Sociological Context 1, i. 1 (2020): 66-75. 